\title{
Representasi Perempuan dalam Iklan Rokok
}

\author{
Arina Rahmatika \\ Sekolah Tinggi Agama Islam Sunan Pandanaran Yogyakarta \\ e-mail: arina.eljawie@gmail.com
}

\begin{abstract}
Cigarette advertisement is one of the ads that has an interesting concept because it is limited by some laws. So inevitably, demand that cigarette's advertisement thinks harder in their efforts to display a cigarette without displaying the shape and embodiment of its product. So, don't be surprised if cigarette advertisement can cause many interpretations and even cause contradiction in society. This case of cigarette advertisement A MILD Edition "Mula Mula Malu-Malu, Lama Lama Mau". Based on the results of research by using analysis of Roland Barthes, then cigarette advertising shows that the advertisement does not apply of the principle of gender equality and woman's emancipation, even advertising tend to be patriarchy, bend and change the image of woman in accordance with the product offered.
\end{abstract}

Keyword: Advertisement, cigarette, woman

\begin{abstract}
Abstrak
Iklan rokok merupakan salahsatu iklan yang memiliki konsep menarik karena dibatasi oleh beberapa undang-undang. Sehingga menuntut para pembuat iklan rokok berpikir lebih keras dalam usahanya menampilkan sebuah iklan rokok tanpa menampilkan bentuk dan perwujudan produknya. Maka tidak heran jika iklan rokok dapat menimbulkan banyak interpretasi bahkan menimbulkan prokontra di masyarakat. Salah satunya adalah Iklan Rokok A MILD Edisi "Mula Mula Malu-Malu, Lama Lama Mau". Berdasarkan hasil penelitian dengan menggunakan metode kualitatif deskriptif dan analisa semiotika Roland Barthes, maka Iklan Rokok A MILD Edisi "Mula Mula Malu-Malu, Lama Lama Mau" memperlihatkan bahwa iklan rokok tersebut tidak menerapkan prinsip persamaan gender dan emansipasi perempuan, bahkan iklan cenderung bersifat patriarki dan membentuk serta pengubahan citra perempuan sesuai dengan produk yang ditawarkan.
\end{abstract}

Kata kunci: Iklan, Rokok, Perempuan 


\section{A. Pendahuluan}

Periklanan atau advertising merupakan kegiatan pemasaran jasa atau barang melalui media massa. (Wahyu Wibowo, 2003: 5) Periklanan sebagai alat pemasaran terdiri atas informasi dan gagasan tentang suatu produk yang ditujukan kepada masyarakat secara serentak agar memperoleh sambutan baik. (Krishna, 2015:57) Oleh karena itu iklan berusaha untuk memberikan informasi, membujuk dan meyakinkan masyarakat bahkan memengaruhi masyarakat. Sehingga secara tidak langsung dapat diartikan, iklan merupakan suatu sumber informasi atau hanya suatu bentuk hiburan bagi masyarakat yang mengonsumsi sesuatu produk ataupun jasa suatu kelompok masyarakat. Secara umum iklan membantu menjelaskan akan suatu produk, sedangkan bagi perusahaan itu sendiri iklan merupakan suatu alat pemasaran yang sangat penting bagi perusahaan.

Dalam hal ini, iklan memuat ideologi tertentu, sehingga dapat dikatakan iklan memiliki suatu bentuk "kekuasaan" dalam masyarakat. Bahkan, iklan berperan besar dalam menentukan kecenderungan, trend mode, dan membentuk kesadaran serta konstruksi berpikir modern. Selain itu juga, melalui media iklan, produsen barang atau jasa mencoba untuk merepresentasikan sebuah citra dan gaya hidup yang seolah-olah dapat diperoleh oleh mereka yang mengonsumsinya. (Eriyanto: 2005: 114) Hal ini semakin didukung dengan penggunaan bahasa-bahasa persuatif dalam teks iklan yang dikemas dengan menarik, mudah dipahami dan kontekstual serta disisipkan dengan makna-makna tersendiri yang seolah-olah memberikan harapan kepada para konsumen untuk menggunkan produk tersebut, sehingga masyarakat tertarik dengan produk yang diklankan. Maka tidak heran jika semiotika memainkan peran yang paling penting dalam studi tentang iklan, karena iklan adalah suatu media yang dibangun oleh tanda dengan berbagai sistem tanda yang bekerjasama dengan baik untuk mencapai efek yang diharapkan karena melalui isi teks iklan diproduksi dengan motif-motif ideologis tertentu yang sesuai dengan kepentingan pembuat iklan tersebut. Oleh karena itu teks dan unsur-unsur 
lain yang terdapat pada iklan menjadi fenomena tersendiri yang menarik untuk diamati.

Dari tanda-tanda dalam iklan itulah kemudian memberikan citra-citra dalam pemaknaan tanda-tanda yang diiklankan bahwa ada suatu hal yang diharusnya ditiru, memperlihatkan kebenaran palsu yang seakan-akan iklan yang ditayangkan mengubah tampilan bahkan perspektif masyarakat. Seringkali kita menemukan pesan dalam iklan yang mengandung kontradiksi citra ideal dan realita yang mempengaruhi ideologi terhadap kesadaran kolektif masyarakat, dimana kontradiksi ini berhubungan dengan norma-norma atau nilai-nilai di masyarakat bahkan membawa efek negatif. Namun karena terus berlangsung maka secara tidak langsung membudaya dan menjadi nilai bahkan gaya hidup di masyarakat. Jika demikian maka iklan dapat merepresentasikan suatu hal.

Representasi sebagai proses perekaman gagasan, pengetahuan, atau pesan secara fisik. Secara lebih tepat dapat di definisikan sebagai penggunaan tanda-tanda untuk menampilkan ulang sesuatu yang diserap, di indra, di bayangkan, atau di rasakan dalam bentuk fisik. (Evi Setyarini, 2010:15) Representasi merujuk kepada konstuksi segala bentuk media terutama media massa terhadap segala aspek realitas atau kenyataan seperti masyarakat, objek, peristiwa, hingga identitas budaya. Representasi ini bisa berbentuk kata-kata atau tulisan bahkan juga dapat dilihat dalam bentuk gambar bergerak atau film. Representasi tidak hanya melibatkan bagaimana identitas budaya disajikan atau di konstruksikan di dalam sebuah teks tapi juga dikonstruksikan di dalam proses produksi dan persepsi oleh masyakarat yang mengkonsumsi nilai budaya yang di representasikan.

Salah satu hasil representasi adalah representasi mengenai perempuan. Citra perempuan yang dibentuk oleh setiap pengiklan berpengaruh terhadap image dari produk mereka. Oleh karena itu setiap pengiklan cenderung menampilkan citra perempuan yang berbeda antara satu dengan yang lainnya untuk menarik calon konsumen dan memenangkan persaingan antara produk sejenis. Dalam iklan, citra 
produk ditampilkan dan diasosiasikan melalui pesan iklan (endoser). Dalam iklan, perempuan sering ditampilkan sebagai objek. Seperti dalam iklan produk kecantikan, dimana pengiklan berlomba-lomba menampilkan figuran perempuan untuk memperlihatkan citra produk yang sesuai dengan standar kecantikan pengiklan.

Sebagaimana bentuk iklan lainnya, iklan rokok merupakan salahsatu iklan yang memiliki konsep berbeda dan menarik. Hal itu dikarenakan dalam penyampaiannya, iklan rokok dibatasi oleh beberapa undang-undang seperti Undang-Undang No.32 tahun 2002 tentang Penyiaran (UU Penyiaran) dan Peraturan Pemerintah (PP) Nomor 109 Tahun 2012. Sehingga mau tidak mau menuntut para pembuat iklan rokok berpikir lebih keras dalam usahanya menampilkan sebuah iklan rokok tanpa menampilkan bentuk dan perwujudan produknya, tetapi tetap membuat konsumen mengetahui jenis produk apa yang diiklankan. Hal ini dikarenakan rokok disebut membahayakan kesehatan bahkan jiwa tingginya angka perokok di Indonesia menyebabkan aturan iklan rokok diatur lebih keras.

Sebagaimana representasi perempuan dalam berbagai iklan lainnya, representasi perempuan juga dibentuk melalui iklan rokok yang ditampilkan oleh media juga mampu menciptakan kesadaran kolektif dan penerimaan masyarakat akan nilai-nilai dan budaya yang dibawa oleh iklan tersebut. Dalam periklanan, media pesan yang disampaikan turut mempengaruhi pesan yang disampaikan secara cepat kepada masyarakat luas. Iklan tersebar melalui media elektronik dan media cetak ataupun media lainnya. Salahsatu bentuk media iklan rokok adalah dengan menggunakan billboard, dimana billboard merupakan reklame yang dipasang dijalan-jalan atau tempat yang strategis lainnya.

Pada beberapa waktu yang lalu terdapat sebuah iklah rokok yang menggunakan media billboard yaitu iklan A MILD Edisi "Mula Mula Malu-Malu, Lama Lama Mau" yang dipasang diberbagai sudut kota di Indonesia. Namun baru 
beberapa hari dipasang, muncul petisi dari Hery Chariansyah yang mengatasnamakan Koalisi Masyarakat Sipil untuk Perlindungan Anak dari Zat Adiktif yang berjudul "Stop Reklame Mesum pada Iklan Rokok A Mild" disitus change.org. Adapun isi petisi ini meminta iklan rokok A MILD Edisi "Mula Mula Malu-Malu, Lama Lama Mau" ditarik dari peredaran karena dinilai gambar dalam iklan rokok tersebut mengandung pesan negatif kepada masyarakat karena terdapat pesan bernada mesum sehingga papan iklan tersebut harus diturunkan.

Seperti yang diberitakan makassar.tribunnews.com dengan judul Sampoerna Turunkan Iklan Mula-Mula Malu-Malu, gambar yang dipersoalkan yaitu visualisasi atas gambar seorang laki-laki sedang memeluk punggung perempuan dan perempuan merangkul pundak laki-laki. Wajah merekapun berdekatan satu sama lainnya. Kemudian di sebelahnya tertulis tagline "Mula - Mula Malu Malu, Lama - lama Mau." Dalam petisi itu, iklan dinilai mengandung pesan yang dianggap seolah-olah mengajak pasangan luar nikah melakukan tindakan asusila karena seolah mengindikasikan bahwa hubungan antara laki-laki dan perempuan itu pada mula-mulanya malu-malu tetapi lama-lama mau. Setelah mendapatkan tanggapan dari masyarakat tersebut, PT HM Sampoerna memutuskan untuk menurunkan seluruh billboard iklan A MILD Edisi "Mula Mula Malu-Malu, Lama Lama Mau” dan meminta maaf kepada masyarakat Indonesia karena telah menampilkan iklan tersebut.

Dalam menyampaikan pesannya, setiap iklan rokok selalu mengandung pesan yang tersembunyi. Begitu pula dengan tampilan iklan rokok A MILD Edisi "Mula Mula Malu-Malu, Lama Lama Mau” yang memiliki banyak interpretasi dikalangan masyarakat luas. Sehingga tidak salah jika Iklan Rokok A MILD Edisi "Mula Mula Malu-Malu, Lama Lama Mau" menjadi salah satu iklan kontroversi pada tahun 2015. Hal itu dikarenakan iklan ini mempunyai arti yang berbeda tergantung kepada orang yang mengartikan atau merepresentasikan konsep-konsep sedemikian rupa yang memungkinkan seseorang membaca atau 
menginterpretasikan makna lain. Oleh karena itu, iklan kontroversial ini menarik untuk dikaji lebih lanjut dalam sebuah penelitian mengenai isu perempuan yang ditampilkan dalam Iklan Rokok A MILD Edisi "Mula Mula Malu-Malu, Lama Lama Mau".

\section{B. Metode Penelitian}

Penelitian yang digunakan adalah dengan metode penelitian kualitatif yang berupa analisis semiotika Roland Barthes dengan fokus penelitian pada Iklan Rokok A MILD Edisi “Mula Mula Malu-Malu, Lama Lama Mau”. Teknik pengumpulan data yang dilakulan adalah dengan dokumentasi dan studi pustaka. Dokumentasi dalam penelitian ini dengan cara mengamati dengan tidak langsung Iklan Rokok A MILD Edisi “Mula Mula Malu-Malu, Lama Lama Mau”. Kemudian studi pustaka dilakukan sebagai penguat data-data yang telah dikaji lebih awal, dengan cara mengumpulkan data dari buku, internet, jurnal ataupun karya ilmuah lainnya. Selain itu juga, studi pustaka digunakan untuk melihat isu-isu kasus yang berkembang di masyarakat, yang kemudian menjadi interpretasi dalam Iklan Rokok A MILD Edisi "Mula Mula Malu-Malu, Lama Lama Mau”.

Analisis data yang digunakan untuk mengkaji iklan dalam penelitian ini adalah analisis semiotika Roland Barthes. Analisis data ini digunakan dengan tujuan untuk mengolah dan menganalisis makna konotasi, denotasi dan mitos, yang kemudian diinterpretasikan dalam representasi perempuan dalam iklan rokok A MILD Edisi "Mula Mula Malu-Malu, Lama Lama Mau”. Adapun unit yang dianalisis yang diguanakan adalah keseluruhan tanda yang terdapat dalam iklan, baik tanda denotative dan konotatif serta mitos yang terbentuk.

\section{Hasil dan Pembahasan}

\section{C.1 Level signifikasi denotasi}

1. Tanda verbal

Dalam iklan diatas menghadirkan judul sebagai tanda verbal yang menuliskan "Mula Mula Malu-Malu, Lama Lama Mau” yang berada di sebelah kiri. 
Kemudian symbol huruf "A" dan tulisan "Go Ahead" berada disebelah kanan. Sedangkan tulisan "peringatan: Rokok membunuhmu" berada dibawah tanda visual. Kemudian di pojok kanan bawah terdapat tulisan "18+". Visual iklan tersebut dapat dilihat pada gambar 1 dibawah ini.

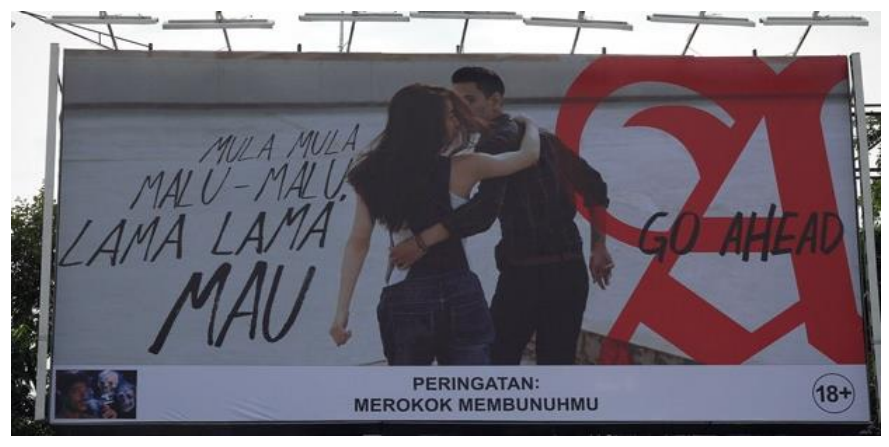

Gambar 1

Iklan Billboard Rokok A MILD “Mula Mula Malu-Malu, Lama Lama Mau” di Jakarta

\section{Tanda visual}

Iklan visual berada di tengah dengan menghadirkan seorang laki-laki dan perempuan muda yang saling bertatapan dan seperti akan berciuman dengan satu tangan masing-masing berangkulan. Keduanya ditampilkan dalam bentuk membelakangi penonton dengan bagian yang ditunjukan adalah kepala sampai lutut dengan background menggunakan warna putih.

Sosok perempuan yang dihadirkan berambut panjang sepunggung dengan menggunakan baju putih berlengan pendek dan celana monyet. Dengan wajah menghadap ke kanan dan memperlihatkan rambut yang terurai menghalangi pandangan dengannya dengan sosok laki-laki serta tangan kanan memegang pundak kanan laki-laki.

Sedangkan untuk sosok laki-laki menggunakan kemeja kotak-kotak dengan lengan baju dilipat sampai setengah lengan dan celana berwarna hitam. Dengan tangan kiri memegang pinggul sebelah kiri perempuan dan wajahnya mengahadap 
ke kiri dan tangan kiri menggunakan gelang. Dibawah pojok kiri terdapat gambar berbentuk kotak yang berisi gambar tengkorak dan orang yang sedang menghisap rokok.

\section{C.2 Level signifikasi konotasi}

1. Tanda verbal

Tanda verbal dengan menggunakan kalimat "Mula Mula Malu-Malu, Lama Lama Mau" merupakan suatu kalimat iklan yang dalam bahasa Indonesia bermakna, dahulu merasa tidak suka atau kurang senang tetapi lambat laun akhirnya suka. Kata mula-mula dan lama-lama merupakan kata yang digunakan untuk menunjukan keterangan waktu. Hal itu dapat dilihat dari Kamus Besar Bahasa Indonesia bahwa mula-mula bermakna pertama-tama atau pada mulanya dan bermakna "sejak". Tetapi kemudian setelah digabungkan dengan kata "malu-malu", makna mula-mula lebih tepat bermakna pertama-tama atau pada mulanya. Kemudian makna "malu-malu" dalam KBBI adalah tampaknya merasa malu. Sedangkan lama-lama bermakna lambat laun akhirnya dan bermakna "makin lama makin". Sedangkan suka disini bermakna sungguh-sungguh suka. Sehingga secara tidak langsung bermakna bahwa pada mula nya kalimat ini bermakna mula-malu malu-malu melakukan sesuatu tetapi pada akhirnya lama-lama mau melakukan nya.

Penggunaan simbol A mengartikan bahwa simbol A berwarna merah dengan background putih, menggambarkan kepercayaan diri dan selalu memberikan inisiatif dan menunjukkan merek pemilik tagline yaitu A mild.

Kalimat Go Ahead yang berada disebelah kanan, dalam bahasa Inggris berarti teruskan atau ayo maju atau sebagai bentuk penyemangat diri untuk maju atau bergerak.

Sedangkan tulisan "peringatan: Rokok membunuhmu” berada dibawah tanda visual. Tulisan peringatan tersebut merupakan Peraturan Pemerintah nomor 109 tahun 2012 tentang pengamanan bahan yang mengandung zat aditif berupa produk tembakau bagi kesehatan dan Peraturan Menteri Kesehatan nomor 28 tahun 
2013. Dengan logika penerapan peraturan wajib tersebut pada Juli 2014, rokok tidak mungkin membunuh seseorang kalau orang itu idak membakar dan menghisapny dan yang dapat membunuh itu aktivitas rokokknya bukan rokoknya.

Kemudian di pojok kanan bawah terdapat tulisan "18+" yang menjelaskan mengenai batasan usia. Maksudnya adalah produk rokok untuk 18 tahun keatas dan tidak untuk usia 18 tahun kebawah.

2. Tanda visual

Sepasang pemuda dan pemudi yang diletakkan ditengah billboard menjadikan dirinya sebagai pusat perhatian utama. Ditampilkan dalam posisi membelakangi penonton dan dengan adegan laki-laki dan perempuan yang saling menatap menjadi komposisi yang membuat segala sesuatu yang melekat pada diri model menjadi objek-objek yang akan diperhatikan pembaca.

Gesture yang ditunjukkan dengan saling menatap dan dengan tangan yang saling berangkulan ditafsirkan oleh khalayak menjadi sesuatu hal yang tidak senonoh dan bertentangan dengan norma sosial yang ada di masyarakat bahkan menjadi suatu hal yang sensitif. Sehingga dalam hal ini, iklan terkesan memberikan pesan negatif terhadap masyarakat terlebih dapat memberikan edukasi yang buruk bagi remaja atau kaum muda yang tidak sesuai dengan budaya timur. Tetapi jika dilihat dari kajian iklan, memang iklan diciptakan untuk menarik perhatian publik, salah satunya melalui hal yang berbau kontroversi. Sedangkan untuk gambar orang merokok dengan asap membentuk tengkorak merupakan peringatan bahwa rokok dapat menyebabkan kematian.

3. Level signifikasi mitos

Melalui petanda-petanda yang ditampilkan, diperoleh makna-makna citra yang ditampilkan dalam Billboard yang menhadrikan sepasang model dengan tulisan "mula mula malu-malu mau" menggambarkan citra perempuan yang direpresentasikan pemalu. Dalam hal ini menegaskan posisi wanita yang inferior dalam kultur yang didominasi pria sehingga perempuan dianggap sosok yang tidak 
konsisten dalam menentukan sikap. Sedangkan laki-laki menjadi sosok yang superior sehingga bisa mendominasi perempuan.

Selain itu juga, secara tidak langsung iklan menggiring pembaca kepada sterotip bahwa laki-laki yang menggunakan rokok atau perokok tidak memiliki sifat pemalu yang cenderung dianggap sosok yang tidak konsisten. Tetapi sebaliknya, laki-laki perokok merupakan sosok pemberani yang bisa menentukan sikapnya.

\section{C.3 Representasi Perempuan pada Iklan Rokok}

Thamrin Tamagola membagi representasi perempuan pada iklan kedalam lima kriteria yaitu citra pigura, citra pilar, citra peraduan, citra pinggan dan citra pergaulan. (TA Tamagola, 1998:25) Dalam iklan rokok A MILD Edisi "Mula Mula Malu-Malu, Lama Lama Mau”, citra pigura, citra pilar dan citra pinggan tidak ditampilkan. Hal itu dikarenakan berdasarkan level denotasi maupun konotasi, iklan tidak memperlihatkan unsur perempuan pada sisi biologisnya dan kewajibannya sebagai pengurus rumah tangga ataupun mengurus dapur.

Namun, terdapat iklan peraduan yang sangat memperlihatkan sosok perempuan sebagai pemuas seksual laki-laki. Hal itu terlihat dari tagline yang menunjuk pada perempuan yang hanya sebatas pemuas seksual laki-laki. Terakhir adalah citra pergaulan yang menekankan pada usaha perempuan untuk dapat diterima dalam pergaulan. Dalam iklan ini, citra pergaulan menampilkan perempuan dalam bentuk penerimaan fisik, yaitu perempuan hanya dapat diterima dalam pergaulan jika fisiknya sesuai dengan pandangan lingkungan sekitarnya.

Dalam citra pergaulan inilah perempuan cenderung mempunyai posisi dalam iklan, maka tidak heran jika isu seksualitas menjadi bacaan utama dalam membahas mengenai perempuan dalam iklan. Seksualias tubuh ditampilkan dalam iklan melalui berbagai macam pengemasan melalui pesan yang diakomodir dalam 
kode-kode, sehingga iklan dapat cepat diserap dan diterima masyarakat. (Yadi Supriyadi, 2013: 124)

Tom Reichert juga membagi beberapa tipe seksualitas dalm iklan dianaranya nudity, sexual behavior, physical attractives, sexual referents dan sexual embeds. Nudity merupakan gambaran tubuh yang dibungkus dengan pakaian minim atau menggoda. Sexual behavior adalah suatu tindakan yang berkaitan pada perjumpaan dengan hal yang mengarah pada tindakan maupun ciri dari tindakan seksual. Bisa ditampilkan dalam sendiri ataupun berpasangan. Tindakan itu dapat ditampilkan dalam dalam secara individua tau dalam interaksi antarpersonal. Biasanya dengan bahasa tubuh yang provokatif. Dalam hal ini iklan tersebut masuk dalam kategori ini. Karena dalam bentuk sentuhan dengan pasangannya.

Physical atractives adalah kekuatan daya pikat tubuh yang tampil untuk mendukung kerja periklanan. Sexual referents gambar maupun kalimat yang mengarah mendorong dan membangun pada imajinasi seksual. Dengan cara halus menjadi sebuah informasi yang tersirat. Dalam hal ini kalimat "Mula Mula MaluMalu, Lama Lama Mau" termasuk ini karena orang yang melihat iklan akan terdorong pada fantasi berupa motif seksual.

Sedangkan secara garis besar, tubuh yang tampil dalam iklan dibagi menjadi 2 yaitu konkret dan imajinatf. Secara konkret, tubuh ditampilkan sebagai alat sekaligus sasaran dari produk yang dipasarkan. Sedangkan imajinatif adalah tubuh difungsikan sebagai harapan, mimpi atau imajinasi liar. Bahkan difungsikan sebagai pemuasan terhadap hasrat laki-laki mapun perempuan. Dengan slogan malu-malu mau, iklan tersebu menampilkan sebuah hasrat bahwa perempuan adalah objek imajinatif yang paling luar biasa (Yadi Supriyadi, 2013: 125-126). Eksploitasi tubuh lebih bayak dialami kaum perempuan. Struktur dominasi kuasa dan ketundukan yang terbentuk dari dulu susah untuk dihilangkan. Dominasi ini tidak lepas dari keberadaan kelas tertentu yaitu kaum pria melalui berbagai lembaga yng muncul setiap proses pembuatan iklan (Yadi Supriyadi, 2013: 125-124) 
Mengapa perempuan dapat direpresentasikan demikian, maka harus juga dilihat bagaimana peristiwa ditampilkan dan bagaimana pihak-pihak yang terlibat dalam iklan tersebut diposisikan. Dalam hal ini, siapa aktor yang dijadikan sebagai subjek dan siapakah yang ditampilkan sebagai objek mempengaruhi analisa atas bagaimana posisi yang ditampilkan secara luas sehingga akan menyingkap bagaimana ideologi dan kepercayaan yang dominan. Dalam iklan ini, pihak lakilaki dalam iklan ditampilkan sebagai subjek dan wanita sebagai objek yang direpresentasikan. Hal itu dapat terlihat dari bagaimana posisi-posisi yang memarjinalkan perempuan ketika ditampilkan.

Pertama, posisi iklan menunjukkan dalam batas tertentu sudut pandang penceritaan. Iklan yang disajikan kepada khalayak adalah suara tunggal laki-laki sebagai pencerita. Dengan demikian secara tidak langsung, khalayak tergantung sepenuhnya kepada pembuat iklan sebagai juru kebenaran, yang dalam hal ini dari laki-laki.

Kedua, sebagai subjek representasi, laki-laki mempunyai otoritas penuh dalam mengabsahkan penyampaian peristiwa tersebut kepada khalayak. Karena posisinya sebagai subjek, ia bahkan mempunyai keluasan menceritakan cerita dan menafsirkan berbagai tindakan yang membangun peristiwa tersebut dan hasil penafsiran tersebut disampaikan kepada khalayak. Sehingga ketika perempuan menjadi objek representasi, maka posisi wanita selalu didefinisikan, dijadikan bahan pencitraan dan tidak bisa menampilkan dirinya sendiri karena otoritas subjek representasi atau laki-laki.

Oleh karena itu, dalam hal ini iklan tersebut mempresentasikan citra prempuan yang pasif dan tidak memiliki peran yang kuat dalam kehidupan sosial serta potret perempuan sebagai objek seksual merupakan dampak komulatif dari gambaran harga diri perempuan, umumnya lahir dari stereotip yang bukan dari mulut perempuan melainkan pihak lain. Sehingga secara tidak langsung perempuan ditampilkan bukan menampilkan dirinya sendiri dan secara tidak langsung 
mengukuhkan dan memperkuat dominasi laki-laki dalam masyarakat, mempromosikan gagasan superioritas dan memarjinalkan perempuan serta mensubordinasikan perempuan.

Selain itu juga, aktor laki-laki yang muncul adalah sebagai representasi kekuasaan yang disimbolkan dengan daya, kekuatan, kecepatan dan dominasi. Begitu juga dengan otoritas laki-laki sebagai subjek representasi menghasilkan stereotip laki-laki sebagai kaum dominan yang masih sangat kuat sementara perempuan dipandang sebagai hamba atau sekedar objek. Dalam hal lain, iklan di atas memperlihatkan peran dan posisi perempuan yang minim dan buram dengan implikasinya adalah perempuan sering dilihat sebagai obyek yang pasif ketimbang sebagai subyek yang aktif.

Ketiga, proses pendefinisian bersifat subjektif sehingga terkesan sepihak. Ia mendefisikan dirinya sendiri dan pihak lain dalam perspektif dari sudut pandangnya sendiri, dalam hal ini sudut pandang laki-laki. Oleh karena itu laki-laki sebagai subjek pencerita bukan hanya menempatkan versi kebenaran mengenai suatu perinstiwa tetapi juga merekonstruksi kebenaran.

Maka tidak heran, dalam iklan tersebut mengisahkan mengenai perempuan yang dicitrakan pemalu sehingga dia tidak mempunyai pendirian. Hal itu dikarenakan laki-laki dalam iklan tersebut ditempatkan sebagai subjek atau pencerita dan perempuan sebagai objek yang diceritakan. Sifat pemalu yang ditunjukkan melalui diri perempuan itu sendiri sehingga terkesan memarjinalkan perempuan karena perempuan tidak berbicara sendiri mengenai dirinya.

Karena iklan tersebut dibuat prespektif laki-laki maka jika tidak salah jika perempuan ditempatkan sebagai objek dan laki laki menjadi subjek. Teks dalam iklan tersebut berbunyi "mula-mula malu-malu lama-lama mau" menegaskan posisi perempuan yang marginal. Metafora tersebut ditunjukkan melalui inerpretasi gambar dalam iklan tersebut. Anehnya kenapa teks tersebut dikenakan kepada perempuan? Kenapa tidak untuk laki-laki? Khalayak seakan diajak lebih 
menggunakan teks tersebut untuk perempuan dibandingkan untuk laki-laki. Hal ini tidak bisa dihindari karena sudut pandang yang digunakan adalah perspektif lakilaki.

Kemudian jika ditarik lebih jauh lagi maka pesan teks tersebut menggambarkan bahwa laki-laki yang tidak merokok seperti halnya perempuan yang malu-malu tapi sebenarnya mau, sehingga disimpulkan menajdi laki-laki yang tidak gentle ketika tidak merokok. Selain itu juga, dalam melihat posisi pembaca maka harus dilihat bagaimana teks dalam iklan membangun suatu model yang menghubungkan antara teks dan penulis disatu sisi, dengan teks dan pembaca disisi lain. Ada beberapa cara yaitu pertama, melihat teks bukan hanya berhubungan dengan faktor produksi tetapi juga resepsi.

Pada kasus iklan rokok A mild juga dapat dilihat bagaimana konstruksi citra perempuan yang digunakan untuk mengiklankan barang dalam hal ini rokok, yang sasaran utamanya adalah laki-laki. Namun dari teks iklan tidak hanya menyasar laki-laki tetapi juga perempuan terhadap versi iklan tersebut. Dalam hal ini, teks iklan diatas menegaskan posisi wanita yang inferior dalam kultur yang didominasi pria. Perempuan dianggap sosok yang tidak konsisten dalam menentukan sikap dan seolah-olah paradigma ini mengakar pada budaya masyarakat Indonesia.

Perempuan lebih sering digambarkan sebagai pribadi yang tugasnya berkaitan dnegan rumah tangga, pengasuhan anak, pemeliharaan rumah, pengabdian maupun berbagai jenis ketundukan yang berlangsung di pengabdian maupun ditempat kerja. Visi domiasi maskulin yang membedakan perempuan dan laki-laki berdasarkan jenis kelamin telah mengarahkan perempuan untuk melakukan pekerjaan yang dianggap remeh, ringan serta rendah yang dilakukan secara turun temurun dan sukarela.

Maka tidak heran jika dari iklan tersebut terdapat praktik representasi ideologi yang dikonstruksikan oleh kapitalisme (produsen rokok) yang mengukuhkan tatanan sosial politik dan budaya patriarki, yang dalam hal ini 
berusaha unuk melegitimasi relasi patriarkis, menjamin otoritas budaya dan menjamin subordinasi perempuan.

Kedua, posisi pembaca ditempatkan dalam posisi yang penting. Posisi pembaca merupakan subjek pembentuk ideologi. Dalam hal ini, posisi pembaca yaitu laki-laki. Hal itu dikarenakan sudut pandang yang digunakan dalam merepresentasikan teks adalah sudut pandang laki-laki. Hal itu dapat diketahui dari penggunaan teks "mula-mula malu-malu lama-lama mau".

Dari teks secara tidak langsung mensugestikan kepada pembaca agar menempatkan dirinya sebagai laki-laki. Kemudian antara subjek dan pengakuan akan posisi dihubungkan secara imajiner dengan kondisi dengan keseluruhan produksi makna yang ada dalam masyarakat. Dari penggunaan teks iklan diatas, maka citra perempua adalah konstruksi yang ideal tentang tentang bagaimana perempuan diberi makna pemalu dan simbol kelemahan, sehingga menjadi sesuatu representasi laki-laki yang tidak merokok. Citra perempuan yang ditunjukkan dalam iklan tidak hanya untuk menjual barang melainkan juga untuk menjual versi tertentu mengenai citra perempuan. Dalam konteks ini, iklan menjadi bersifat ideologis.

Dalam hal ini, seseorang akan menerima dan mengakui posisi perempuan sebagai seorang yang pemalu. Interpelasi disini mengkonstruksi seseorang, membentuk subjek dalam posisinya dengan masyarakat dan bagaimana seharusnya bertindak karena masyarakat menerima hal itu sebagai suatu kenyataan dan suatu kebenaran.

Begitupun juga jika di interkoneksikan dengan rokok. Maka secara tidak langsung, jika dia seorang laki-laki maka agar tidak seperti perempuan, dia haruslah merokok. Kemudian berdasarkan kode budaya membuat khalayak menempatkan dirinya terhadap orientasi nilai yang disetujui dan dianggap benar oleh pembaca. Sepeti iklan rokok diatas yang mensugestikan kalau mau rokok tidak usah malumalu, yang secara tersurat merupakan sarana komunikasi kepada khalayak 
konsumen sebagai sasaran yang dominan laki-laki. Padahal tidak ada hubungan pasti yang logis antara merokok dengan kejantanan atau dalam hal ini tidak pemalu. Tetapi iklan memberikan kekuatan citra untuk mereduksi hal tersebut, sehingga tidak heran jika periklanan penuh dengan identifikasi suatu citraan.

Aspek iklan dimainkan oleh citra dan secara umum interpretasi harfiah terhadap iklan sepadan dengan janji yang ditawarkan. Sementara interpretasi metaforik memperlihatkan cara menuju kekuatan mitologis di belakang janji tersebut menjadikannya berbeda secara kultural dan bermakna bagi pembacanya. Maka iklan tersebut tidak dirancang untuk orang-orang yang menyerupai seperti yang ada di iklan, tetapi bagi orang yang ingin menjadi seperti dirinya.

Jika iklan diatas dihubungkan dengan gender, konsep perempuan ideal yang dibangun oleh iklan rokok diatas cenderung menempatkan perempuan sebagai objek tatapan. Hal ini ditandai dengan panduan teknik sinematrografi media yang menganggap mata kamera adalah mata laki-laki sehingga tampilan perempuan di dalam media tidak lepas dari kuasa mata lelaki. Dalam prinsip ini perempuan menempati posisi sebagai subjek yang tidak mempunyai kuasa atas dirinya sendiri tetapi tunduk pada kekuasaan laki-laki. Jika laki-laki ditampilkan sebagai sosok yang dominan serta kuat secara fisik dan mental maka perempuan akan ditampilkan sebaliknya.

Oleh karena itu, pemajangan perempuan dan laki-laki dengan pose seperti iklan di atas dapat menjual komoditas rokok dan menebarkan versi ideologi tertentu mengenai kejantanan atau maskulinitas. Dalam hal ini berarti yang dimaksudkan dengan kejantanan adalah yang tidak malu-malu merokok.

\section{Penutup}

Representasi perempuan dalam iklan Rokok A MILD Edisi "Mula Mula Malu-Malu, Lama Lama Mau" terlihat dari tanda denotasi, konotasi dan mitos yang mengarah kepada representasi perempuan yang dibentuk oleh pengiklan dan 
memberikan pengaruh terhadap image dari produk iklan rokok A MILD. Pengiklan cenderung menampilkan perempuan hanya untuk menarik calon konsumen dan memenangkan persaingan antara produk sejenis, sehingga perempuan hanya ditampilkan dan diasosiasikan sebagai objek iklan.

Terlepas dari berbagai kontroversi yang ada, Iklan Rokok A MILD Edisi "Mula Mula Malu-Malu, Lama Lama Mau” memberikan representasi perempuan yang cenderung negatif dalam memandang perempuan. Hal itu terlihat dari jenis representasi perempuan yang digunakan dalam iklan dan tipe seksualitas yang mengarah pada perempuan sebagai objek iklan. Tidak hanya itu, perempuan ditempatkan sebagai objek komoditas dan laki-laki sebagai subjek yang mencitrakan. Hal itu berdampak kepada kesetaraan gender yang tidak dibangun dalam iklan ini dan berdampak pada edukasi yang ditampilkan iklan kepada khalayak. Kemudian posisi pembaca yang cenderug bersegmentasi produk untuk laki-laki memperlihatkan bahwa terdapat isu seksualitas dan budaya patriarki turut membentuk representasi perempuan.

\section{Daftar Pustaka}

Alex Sobur, Semiotika Komunikasi, Bandung: PT. Remaja Rosdakarya, 2004.

Benny. H. Hoed, Semiotik dan Dinamika Sosial Budaya. Depok: Komunitas Bambu. 2014.

Eriyanto, Analisis Wacana. Yogyakarta: LKiS, 2001.

Evi Setyarini, dkk. Pesan, Tanda dan Makna : Buku Teks Dasar mengenai Semiotika dan Teori Komunikasi. Jalasutra, Yogyakarta2010,

John Fiske, Pengantar Ilmu Komunikasi, Jakarta: Rajawali Pers, 2012.

Krisna santoso yusat Periklanan dalam perspektif pemasaran.. Jurnal pro bisnis vo.4 no. 1 februari 2011

Ratna Noviani, Jalan Tengah Memahami Iklan, Antara Realitas, Representasi dan Simulasi, Yogyakarta, Pustaka Pelajar. 2002, 
Tamagola TA, Citra Wanita dalam Iklan dalam Majalah Wanita Indonesia: Wanita dan Media, Bandung: Remaja Rosdakarya, 1998.

Wahyu Wibowo, Sihir Iklan: Format Komunikasi Mondial dalam Kehidupan Urban-Kosmopolit, Jakarta: Gramedia Pustaka Utama, 2003.

Yadi Supriyadi, Periklanan Prespektif Ekonomi Politik. Bandung: Simbiosa Rekatama Media, 2013.

Yasraf Amir Piliang, Hipersemiotika: Tafsir Cultural Studies Atas Matinya Makna, Yogyakarta: Jalasutra, 2003. 